\title{
Expression of ascorbate peroxidase and glutathione reductase in roots of rice seedlings in response to $\mathrm{NaCl}$ and $\mathrm{H}_{2} \mathrm{O}_{2}$
}

\author{
Yu-Chang Tsai ${ }^{a}$, Chwan-Yang Hong ${ }^{b}$, Li-Fei Liu ${ }^{a}$, Ching Huei Kao ${ }^{a, *}$
}

\author{
${ }^{a}$ Department of Agronomy, National Taiwan University, Taipei, Taiwan, Republic of China \\ bInstitute of Botany, Academia Sinica, Taipei, Taiwan, Republic of China
}

Received 8 April 2004; accepted 2 June 2004

KEYWORDS

Active oxygen

species;

Ascorbate

peroxidase;

Glutathione

reductase;

Hydrogen peroxide;

Oryza sativa;

Salt stress

\begin{abstract}
Summary
The accumulation of $\mathrm{H}_{2} \mathrm{O}_{2}$ by $\mathrm{NaCl}$ was observed in the roots of rice seedlings. Treatment with $\mathrm{NaCl}$ caused an increase in the activities of ascorbate peroxidase (APX) and glutathione reductase (GR) and the expression of OsAPX and OsGR in rice roots. Exogenously applied $\mathrm{H}_{2} \mathrm{O}_{2}$ also enhanced the activities of $A P X$ and $G R$ and the expression of OsAPX and OsGR in rice roots. The accumulation of $\mathrm{H}_{2} \mathrm{O}_{2}$ in rice roots in response to $\mathrm{NaCl}$ was inhibited by the NADPH oxidase inhibitors, diphenyleneiodonium chloride (DPI) and imidazole (IMD). However, DPI, IMD, and dimethylthiourea, a $\mathrm{H}_{2} \mathrm{O}_{2}$ trap, did not reduce $\mathrm{NaCl}$-enhanced activities of APX and GR and expression of OsAPX and OsGR. It appears that $\mathrm{H}_{2} \mathrm{O}_{2}$ is not involved in the regulation of $\mathrm{NaCl}$-induced APX and GR activities and OsAPX and OsGR expression in rice roots.

(c) 2004 Elsevier $\mathrm{GmbH}$. All rights reserved.
\end{abstract}

\section{Introduction}

Soil salinity, particularly due to $\mathrm{NaCl}$, can be considered as the single most widespread soil toxicity problem that global rice production faces at present. Roots play a number of important roles during plant growth and development and typically are the first part of the plant to encounter soil salinity. When growing in saline soils, roots have to cope with two types of stresses, osmotic and ionic. These stresses in turn cause a reduction in water uptake and inhibition of root growth (Munns, 1993).

The increase in active oxygen species (AOS) seems to occur as a response to most, if not all,

Abbreviations: AOS, active oxygen species; APX, ascorbate peroxidase; DMTU, dimethylthiourea; DPI, diphenyleneiodonium chloride; DW, dry weight; GR, glutathione reductase; GSH, reduced glutathione; GSSG, oxidized glutathione; IMD, imidazole; PVP, polyvinyl-pyrrolidone

*Corresponding author.

E-mail address: kaoch@ntu.edu.tw (C.H. Kao). 
abiotic stresses including drought (Smirnoff, 1993) and salinity (e.g. Dionisio-Sese and Tobita, 1998; Lin and Kao, 2000; Hernández et al., 2001; Lee et al., 2001; Sudhakar et al., 2001; Hernández and Almansa, 2002). These AOS can damage DNA, protein, chlorophyll, and membrane functions. To mitigate and repair damage initiated by AOS, plants have developed a complex antioxidant system (Van Breusegem et al., 2001; del Rio et al., 2002).

Ascorbate peroxidase (APX, EC 1.11.1.1) plays a crucial role in the detoxification of cellular $\mathrm{H}_{2} \mathrm{O}_{2}$, the toxic product of superoxide dismutation. Glutathione reductase (GR, EC 1.6.4.2) is a flavoenzyme and has been found in all organisms examined. This enzyme, which catalyzes the reduction of oxidized glutathione (GSSG) to reduced glutathione (GSH) with the accompanying oxidation of $\mathrm{NAD}(\mathrm{P}) \mathrm{H}$, is thought to be an important reaction of the system for the detoxification of AOS in plants. Therefore, APX and GR have been suggested to be regulated in response to various environmental stresses and to contribute to stress tolerance in APX- and GR-overexpressing plants (Aono et al., 1991; Broadbent et al., 1995; Kubo et al., 1995; Sato et al., 2001). Lee et al. (2001) showed that $\mathrm{NaCl}$ stress resulted in a higher activity of APX in rice leaves but not in rice roots. In shoot cultures of rice, activity of APX was similar whether the shoots were grown in the presence or absence of $\mathrm{NaCl}$ (Fadzilla et al., 1997). In contrast, there was an early increase in GR activity in $\mathrm{NaCl}$ exposed shoot cultures of rice (Fadzilla et al., 1997). Expression of $A P X$ and $G R$ has been reported to be enhanced in plants by $\mathrm{NaCl}$ treatment (Kaminaka et al., 1998; Savoure et al., 1999; Kawasaki et al., 2001). However, Lopez et al. (1996) demonstrated that APX activity, not the mRNA level, was enhanced in $\mathrm{NaCl}$-stressed Raphanus sativus plants.

Recently, many researchers have focused on functional aspects of $\mathrm{H}_{2} \mathrm{O}_{2}$ generation. $\mathrm{H}_{2} \mathrm{O}_{2}$ is a constituent of oxidative metabolism. Because $\mathrm{H}_{2} \mathrm{O}_{2}$ is relatively stable and diffusible through membrane, $\mathrm{H}_{2} \mathrm{O}_{2}$ is thought to constitute a general signal molecule inducing cellular stress (Foyer et al., 1997; Neill et al., 2002). It has been shown that $\mathrm{H}_{2} \mathrm{O}_{2}$ stimulated $A P X$ and $\mathrm{GR}$ activities in maize leaves (Pastori and Trippi, 1992, 1993). $\mathrm{H}_{2} \mathrm{O}_{2}$ induced the expression of gene encoding APX in germinating rice embryos (Morita et al., 1999) and in Arabidopsis leaves (Karpinski et al., 1999). However, the failure of induction of $A P X$ and $G R$ genes by $\mathrm{H}_{2} \mathrm{O}_{2}$ has also been reported (Babiychuk et al., 1995; Vansuyt et al., 1997; Xiang and Oliver, 1998). It has been suggested that cytosolic APX transcripts can be upregulated by increased levels of $\mathrm{H}_{2} \mathrm{O}_{2}$ in tobacco chloroplasts as a result of $\mathrm{Cu}-\mathrm{Zn}$-superoxide dismutase overexpression (Gupta et al., 1993). However, Karpinski et al. (1997) reported that a photooxidative burst of $\mathrm{H}_{2} \mathrm{O}_{2}$ was not involved in the regulation of $A P X 1$ or $A P X 2$ gene expression in Arabidopsis. de Agazio and Zacchini (2001) demonstrated that dimethylthiourea (DMTU), a $\mathrm{H}_{2} \mathrm{O}_{2}$ trap, partially prevented the increase of $A P X$ gene expression in spermidinetreated maize roots. They concluded that induction of APX gene expression in spermidine-treated maize roots is mediated through $\mathrm{H}_{2} \mathrm{O}_{2}$, a spermidine catabolic product.

We have previously shown that $\mathrm{NaCl}$ increases $\mathrm{H}_{2} \mathrm{O}_{2}$ level in roots of rice seedlings ( $\mathrm{Lin}$ and $\mathrm{Kao}$, 2001). In this study, we first examined the effect of $\mathrm{NaCl}$ and $\mathrm{H}_{2} \mathrm{O}_{2}$ on the expression of APX and GR and then the possible interactions between $\mathrm{H}_{2} \mathrm{O}_{2}$ - and $\mathrm{NaCl}$-induced expression of APX and GR in roots of rice seedlings.

\section{Materials and methods}

\section{Plant material}

Rice (Oryza sativa L., cv. Taichung Native 1) seeds were sterilized with $2.5 \%$ sodium hypochlorite for $15 \mathrm{~min}$ and washed extensively with distilled water. In order to get more uniformly germinated seeds, rice seeds in Petri dish $(20 \mathrm{~cm})$ containing distilled water were pre-treated at $37^{\circ} \mathrm{C}$ for 1 day under dark condition. Uniformly germinated seeds were then selected and transferred to a Petri dish $(9.0 \mathrm{~cm})$ containing two sheets of Whatman No. 1 filter paper moistened with $10 \mathrm{~mL}$ of distilled water for 2 days. Two-day-old seedlings were then treated with distilled water, $\mathrm{NaCl}$, or $\mathrm{H}_{2} \mathrm{O}_{2}$ at the desired concentration as specified in the individual experiments. Root growth of rice seedlings grown in distilled water is similar to that grown in medium containing inorganic salts, thus seedlings grown in distilled water were used as the controls. For the experiments to examine the role of $\mathrm{H}_{2} \mathrm{O}_{2}$ in regulating $\mathrm{NaCl}$-induced activities of APX and GR, and expression of OsAPX and OsGR in roots, diphenyleneiodonium chloride (DPI) and imidazole (IMD), which are known to inhibit NADPH oxidase, and DMTU, a chemical trap for $\mathrm{H}_{2} \mathrm{O}_{2}$, were used. Each Petri dish contained 20 germinated seeds. Each treatment was replicated four times. The germinated seeds were allowed to grow at $27^{\circ} \mathrm{C}$ in darkness. 


\section{$\mathrm{H}_{2} \mathrm{O}_{2}$ determination}

The $\mathrm{H}_{2} \mathrm{O}_{2}$ level was colorimetrically measured as described by Jana and Choudhuri (1981). $\mathrm{H}_{2} \mathrm{O}_{2}$ was extracted by homogenizing with phosphate buffer ( $50 \mathrm{mmol} \mathrm{L}^{-1}, \mathrm{pH} 6.8$ ) including $1 \mathrm{mmol} \mathrm{L}^{-1}$ hydroxylamine. The homogenate was centrifuged at $6000 g_{n}$ for $25 \mathrm{~min}$. To determine $\mathrm{H}_{2} \mathrm{O}_{2}$ levels, extracted solution was mixed with $0.1 \%$ titanium chloride (Aldrich) in $20 \%(\mathrm{v} / \mathrm{v}) \mathrm{H}_{2} \mathrm{SO}_{4}$ and the mixture was then centrifuged at $6000 g_{n}$ for $15 \mathrm{~min}$. The intensity of yellow color of supernatant was measured at $410 \mathrm{~nm} . \mathrm{H}_{2} \mathrm{O}_{2}$ level was calculated using the extinction coefficient $0.25 \mu \mathrm{mol}^{-1} \mathrm{~cm}^{-1} . \mathrm{H}_{2} \mathrm{O}_{2}$ level was expressed on the basis of dry weight (DW).

\section{Ascorbate peroxidase and glutathione reductase assays}

For extraction of enzymes, root tissues were homogenized with $0.1 \mathrm{~mol} \mathrm{~L}^{-1}$ sodium phosphate buffer (pH 6.8) containing $0.1 \mathrm{mmol} \mathrm{L}^{-1}$ EDTA, $1 \%$ $(\mathrm{v} / \mathrm{v})$ polyvinyl-pyrrolidone (PVP), and $0.5 \%(\mathrm{v} / \mathrm{v})$ Triton X-100 in a chilled mortar. For analysis of APX activity, $2 \mathrm{mmol} \mathrm{L}^{-1}$ ascorbic acid was added to the extraction buffer. The homogenate was centrifuged at $12,000 \mathrm{~g}_{n}$ for $20 \mathrm{~min}$ and the resulting supernatant was used for determination of enzyme activity. The whole extraction procedure was carried out at $4^{\circ} \mathrm{C}$. APX was determined according to Nakano and Asada (1981). The decrease in ascorbate concentration was followed as a decline in optical density at $290 \mathrm{~nm}$ and activity was calculated using the extinction coefficient $\left[2.8\left(\mathrm{mmol} \mathrm{L}^{-1}\right)^{-1} \mathrm{~cm}^{-1}\right.$ at $290 \mathrm{~nm}$ ] for ascorbate. One unit of APX was defined as the amount of enzyme that breaks down $\mu \mathrm{mol}$ of ascorbate per minute. GR was determined by the method of Foster and Hess (1980). One unit of GR was defined as the amount of enzyme that decreases $1 A_{340} \min ^{-1}$. Activities of all enzymes were expressed on the basis of DW.

\section{Isolation of OsAPX and OsGR cDNA}

Rice cDNA clones encoding OsAPX and OsGR were isolated through RT-PCR approach using root RNA as template. Total RNA was isolated from hydroponically cultivated rice roots using the TRIZOL reagent and following manufacture's instructions (Invitrogen Life Technologies, Carlsbad, CA). Using $1 \mu \mathrm{g}$ of template RNA, OsAPX $(0.8 \mathrm{~kb})$ and OsGR $(1.6 \mathrm{~kb})$ CDNA were amplified by Super Script ${ }^{T M}$ one-step RTPCR with Platinum ${ }^{\circledR}$ Taq (Invitrogen ${ }^{\circledR}$ ), respectively. The gene-specific primers were designed according to the CDNA sequences published in NCBI
GeneBank (accession numbers: OsAPX, AY254495; OsGR, D78136). The primer pairs used for the RTPCR were: OsAPX, 5'-TTCGAATTCTCCACCCGCAGCCAT GGCGA-3' (EcoRI site underlined) and 5'ACTGTCTAGAACGG GCAATGTACT AGGCAGT-3' (Xbal site underlined); OsGR, 5'-AGCGAATTCTTGAGGATCCAT GGC-3' (ECORI site underlined) and 5'-TCATCTAGACCAGAGTACACTTTGCC-3' (Xbal site underlined). The PCR products were subcloned into the EcoRI and Xbal sites of pBluescript (Strategene) to generate $\mathrm{pBS} / \mathrm{APX}$ and $\mathrm{pBS} / \mathrm{GR}$, respectively.

\section{RNA gel blot Analysis}

RNA gel blot analysis was employed to study OsAPX and $O s G R$ transcription levels in roots following different treatments. Sample of $7 \mu \mathrm{g}$ of total RNA was size fractionated on $1 \%$ agarose gel containing $10 \mathrm{mmol} \mathrm{L}^{-1}$ sodium phosphate buffer $(\mathrm{pH} 6.5)$, transferred to a nylon filter, and hybridized with ${ }^{32} \mathrm{P}$ random primer labeled OsAPX DNA $(0.8 \mathrm{~kb})$ or OsGR DNA (1.6 kb) probe (Thomas, 1983). All hybridization reagents were prepared as described in Sambrook et al. (1989). The hybridization signals were scanned (Microtek ScanMaker 8700 scanner, software Quantity One, Bio-Rad), and the ratio of OsAPX and OsGR mRNA to 18S rRNA was determined. The results are expressed as the degree of increase over mRNA levels for the untreated roots.

\section{Statistical analysis}

The results presented were the means of four replicates. Means were compared by either Student's $t$-test or Duncan's multiple range test.

\section{Results}

The changes in APX and GR activities in roots of rice seedlings after treatment of $150 \mathrm{mmol} \mathrm{L}^{-1}$ are presented in Figs. $1 \mathrm{~B}$ and $\mathrm{C}$. $\mathrm{NaCl}$ treatment had higher activities of $\mathrm{APX}$ and $\mathrm{GR}$ than the controls. $\mathrm{NaCl}$ treatment caused an increase in $\mathrm{H}_{2} \mathrm{O}_{2}$ content in rice roots (Fig. $1 \mathrm{~A}$ ). The increase in $\mathrm{H}_{2} \mathrm{O}_{2}$ was evident at $8 \mathrm{~h}$ after treatment of $\mathrm{NaCl}$. These results suggest that $\mathrm{H}_{2} \mathrm{O}_{2}$ may play an important role in regulating the increase of $A P X$ and $G R$ activities in rice roots treated with $\mathrm{NaCl}$.

To test whether $\mathrm{H}_{2} \mathrm{O}_{2}$ is involved in $\mathrm{NaCl}$-induced APX and GR activities in roots of rice seedlings, DMTU, a chemical trap for $\mathrm{H}_{2} \mathrm{O}_{2}$ (de Agazio and Zacchini, 2001) was used. Roots of rice seedlings were pre-treated with or without $5 \mathrm{mmol} \mathrm{L}^{-1}$ DMTU for $12 \mathrm{~h}$. As indicated in Figs. $2 \mathrm{~B}$ and $\mathrm{C}$, when rice 

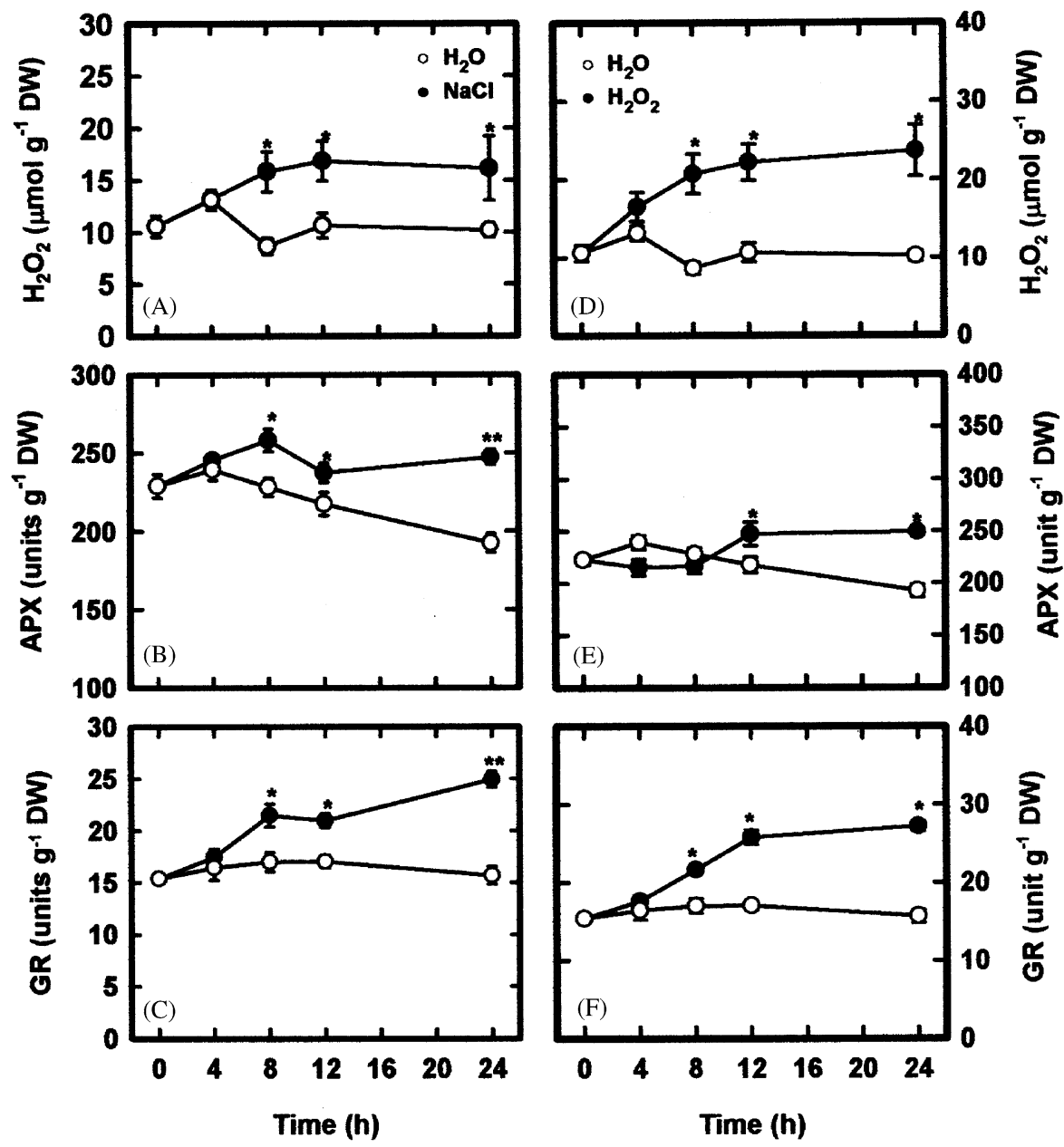

Figure 1. Changes in the levels of $\mathrm{H}_{2} \mathrm{O}_{2}(A, D)$ and the activities of $A P X(B, E)$ and $G R(C, F)$ in $\mathrm{H}_{2} \mathrm{O}-$, $\mathrm{NaCl}$, and $\mathrm{H}_{2} \mathrm{O}_{2}$ treated roots of rice seedlings. Two-day-old rice seedlings were treated with either distilled water or $\mathrm{NaCl}$ $\left(150 \mathrm{mmol} \mathrm{L}^{-1}\right)$ or $\mathrm{H}_{2} \mathrm{O}_{2}\left(10 \mathrm{mmol} \mathrm{L}^{-1}\right) .{ }^{*}$ and ${ }^{* *}$ indicate significance at $P<0.05$ and $P<0.01(n=4)$, respectively, by Student's $t$-test when compared to water control.

roots were pre-treated with DMTU, $\mathrm{NaCl}$-induced $A P X$ and GR activities in rice roots were not reduced. AOS originating from the plasma-membrane NADPH oxidase, which transfers electrons of cytoplasmic NADPH to $\mathrm{O}_{2}$ to form $\mathrm{O}_{2}^{-}$, followed by dismutation of $\mathrm{O}_{2}^{-}$to $\mathrm{H}_{2} \mathrm{O}_{2}$, has been a recent focus in AOS signaling. In several model systems investigated in plants, the oxidative burst and accumulation of $\mathrm{H}_{2} \mathrm{O}_{2}$ appear to be mediated by the activities of plasma-membrane NADPH oxidase complex (Pei et al., 2000; Orozco-Cárdenas et al., 2001; Jiang and Zhang, 2002, 2003). When rice roots were pretreated with DPI or IMD, which is known to inhibit NADPH oxidase (Pei et al., 2000; Cross, 1990; Orozco-Cárdenas et al., 2001; Jiang and Zhang, $2002,2003)$, it was observed that $\mathrm{NaCl}$-induced accumulation of $\mathrm{H}_{2} \mathrm{O}_{2}$ was significantly reduced (Fig. 2A). However, DPI and IMD pre-treatments had no effect on $\mathrm{NaCl}$-induced $\mathrm{APX}$ and $\mathrm{GR}$ activities in rice roots (Figs. $2 \mathrm{~B}$ and $\mathrm{C}$ ).
The effect of $150 \mathrm{mmol} \mathrm{L}^{-1} \mathrm{NaCl}$ on the expression of genes of APX and GR is shown in Figs. 3A and $B$. The steady-state transcript levels of OsAPX and $O s G R$ increased after $\mathrm{NaCl}$ treatment. However, $\mathrm{NaCl}$-induced expression of OsAPX and OsGR in rice roots was not reduced by pre-treatment of DPI and DMTU (Figs. 3A and B).

Exogenous application of $\mathrm{H}_{2} \mathrm{O}_{2}$ resulted in an increase in the content of $\mathrm{H}_{2} \mathrm{O}_{2}$ (Fig. 1D), the activities of APX and GR (Figs. $1 \mathrm{E}$ and $\mathrm{F}$ ) and the transcript levels of OSAPX and OSGR in rice roots (Figs. 4A and $B$ ).

\section{Discussion}

Environmental stresses are known to cause oxidative stress within plant cells. The accumulation of $\mathrm{H}_{2} \mathrm{O}_{2}$ has been observed in response to chilling 


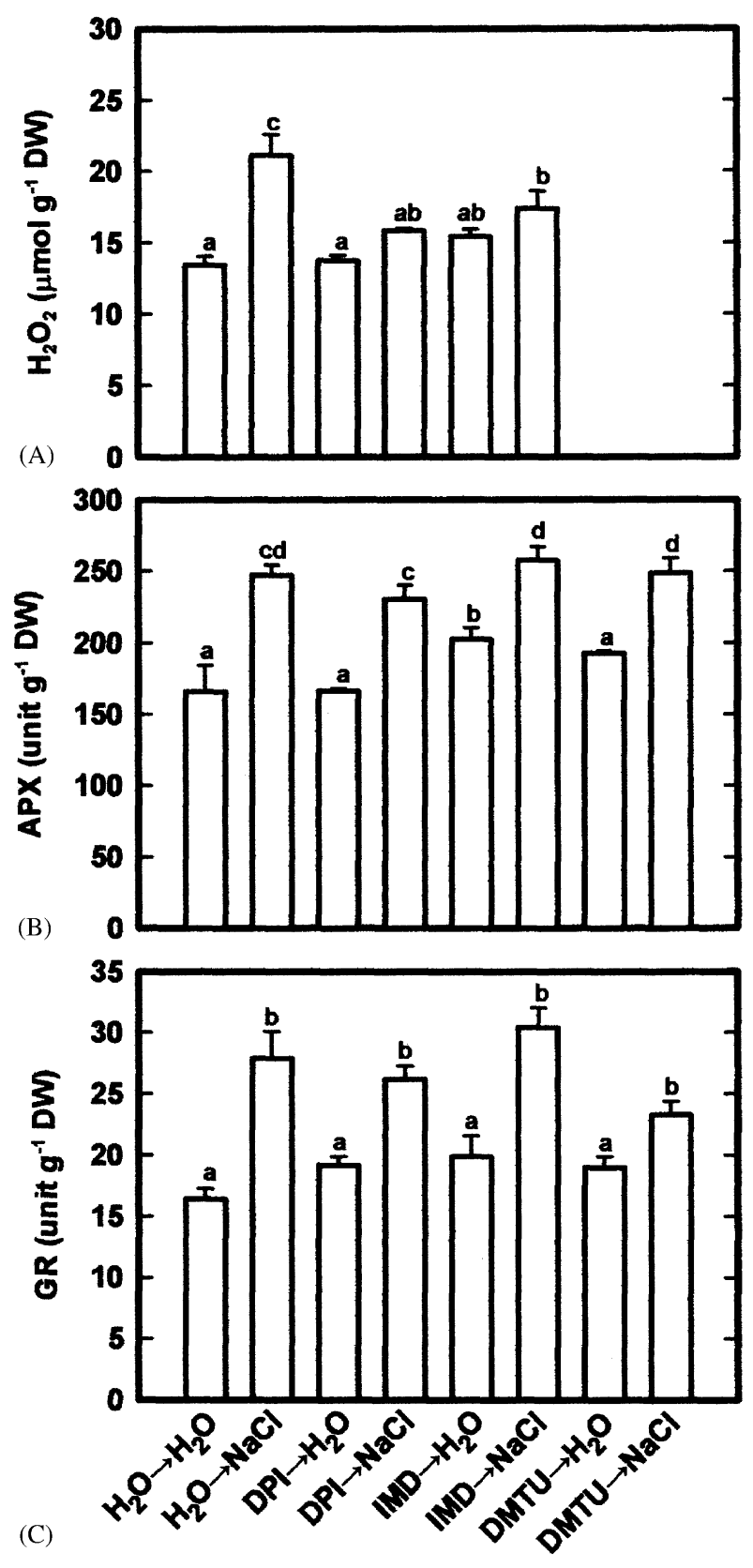

Figure 2. Effect of DPI and IMD pre-treatments on the levels of $\mathrm{H}_{2} \mathrm{O}_{2}(\mathrm{~A})$ and DMTU, DPI, IMD on the activities of APX (B) and GR (C) in the roots of rice seedlings in the presence or absence of $\mathrm{NaCl}$. Two-day-old rice seedlings were pre-treated with distilled water or DMTU $\left(5 \mathrm{mmol} \mathrm{L}^{-1}\right)$, DPI $\left(0.1 \mu \mathrm{mol} \mathrm{L}^{-1}\right)$ or IMD $\left(10 \mathrm{mmol} \mathrm{L}^{-1}\right)$ for $12 \mathrm{~h}$ and then transferred to distilled water and $\mathrm{NaCl}$ $\left(150 \mathrm{mmol} \mathrm{L}^{-1}\right)$ for $24 \mathrm{~h}$, respectively. Means followed by the same letter do not differ significantly at $P<0.05$ $(n=4)$ by Duncan's multiple range test.

(Okuda et al., 1991; Prasad et al., 1994; O’Kane et al., 1996; Fadzilla et al., 1996), heat (Dat et al., 1998), UV radiation (Murphy and Huerta, 1990), excess light (Karpinski et al., 1997), and anoxic stress (Blokhina et al., 2001). Lee et al. (2001) showed that $\mathrm{NaCl}$ treatment resulted in an accumulation of $\mathrm{H}_{2} \mathrm{O}_{2}$ in the leaves but not in the roots of rice plants. Here, we show that $\mathrm{H}_{2} \mathrm{O}_{2}$ levels accumulate in $\mathrm{NaCl}$-treated roots of rice seedlings (Fig. $1 \mathrm{~A}$ ). $\mathrm{NaCl}$-induced accumulation of $\mathrm{H}_{2} \mathrm{O}_{2}$ in rice leaves has been suggested to be due to $\mathrm{NaCl}$ enhanced SOD and $\mathrm{NaCl}$-deactivated CAT activities (Lee et al., 2001). This does not seem to be the case in the roots of rice seedlings, because $\mathrm{NaCl}$ had no effect on SOD and CAT activities (unpublished observation).

It has been shown that high concentration of DPI can affect other enzymes potentially involved in the generation of AOS, including cell wall peroxidase and nitric oxidase synthase (Bolwell et al., 1998; Frahry and Schopfer, 1998; Stuehr et al., 1991). The fact that $\mathrm{NaCl}$-induced $\mathrm{H}_{2} \mathrm{O}_{2}$ accumulation in rice roots can be inhibited by low concentration DPI $\left(0.1 \mu \mathrm{mol} \mathrm{L}^{-1}\right)$ and can be inhibited by IMD $\left(10 \mathrm{mmol} \mathrm{L}^{-1}\right)$, another inhibitor of NADPH oxidase (Cross, 1990, Fig. 2A), strongly suggested that $\mathrm{NaCl}$-induced accumulation of $\mathrm{H}_{2} \mathrm{O}_{2}$ was mediated through the activation of NADPH oxidase in rice roots. NADPH oxidase does not seem to be the only source $\mathrm{H}_{2} \mathrm{O}_{2}$ generation in $\mathrm{NaCl}$-treated rice roots, because $\mathrm{NaCl}$-induced cell wall bound $\mathrm{NADH}$ peroxidase and diamine oxidase activities, which devoted to $\mathrm{H}_{2} \mathrm{O}_{2}$ generation, have been detected in the roots of rice seedlings (Lin and Kao, 2001).

The role of APX and GR in the $\mathrm{H}_{2} \mathrm{O}_{2}$ scavenging in plant cells has been well established in ascorbate-glutathione cycle (Bowler et al., 1992). APX and GR activities have been shown to be enhanced by $\mathrm{NaCl}$ stress in rice leaves (Lee et al., 2001) and rice shoots cultured in the presence of $\mathrm{NaCl}$ (Fadzilla et al., 1997). There are other reports showing that $\mathrm{NaCl}$ had no effect on APX activity in rice roots (Lee et al., 2001). Here, we show that both APX and GR activities are enhanced by $\mathrm{NaCl}$ in roots of rice seedlings (Figs. $1 \mathrm{~B}$ and $\mathrm{C}$ ).

The results of the present study seem to be contradictory to those of Lee et al. (2001), who demonstrated that $\mathrm{NaCl}$ had no effect on $\mathrm{H}_{2} \mathrm{O}_{2}$ levels and APX activity in rice roots. This difference may be due to the different rice cultivars used.

Gene expression in response to environmental stress is usually studied at the level of steady-state mRNA abundance because this gives a more precise estimate of antioxidant gene activation than enzyme activity. Expression of $A P X$ and $G R$ has been demonstrated to be enhanced in plants by $\mathrm{NaCl}$ treatment (Kaminaka et al., 1998; Savoure et al., 1999; Kawasaki et al., 2001). However, Lopez 

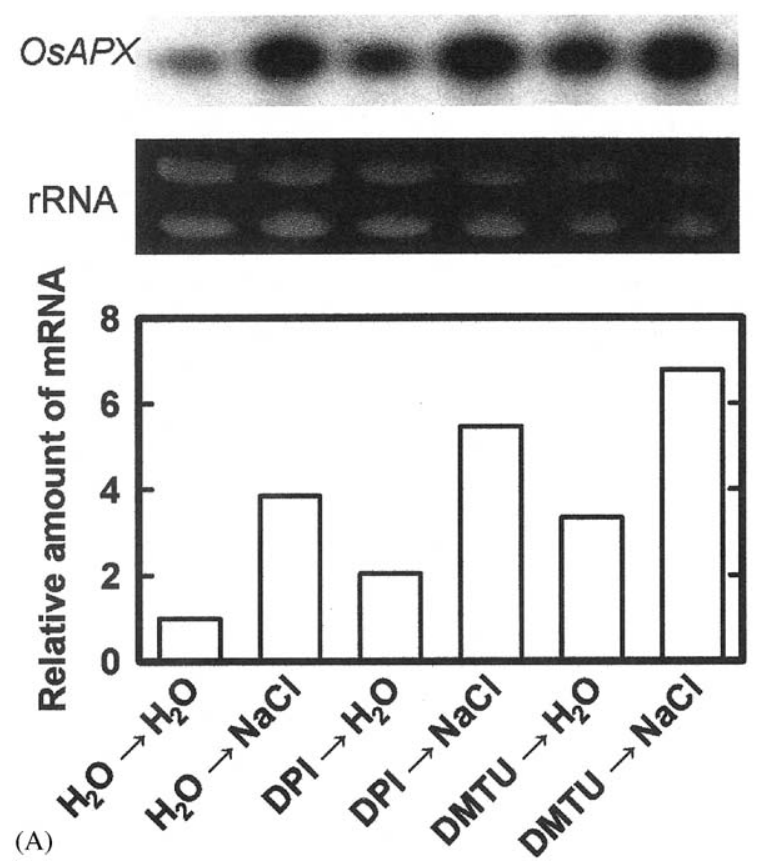

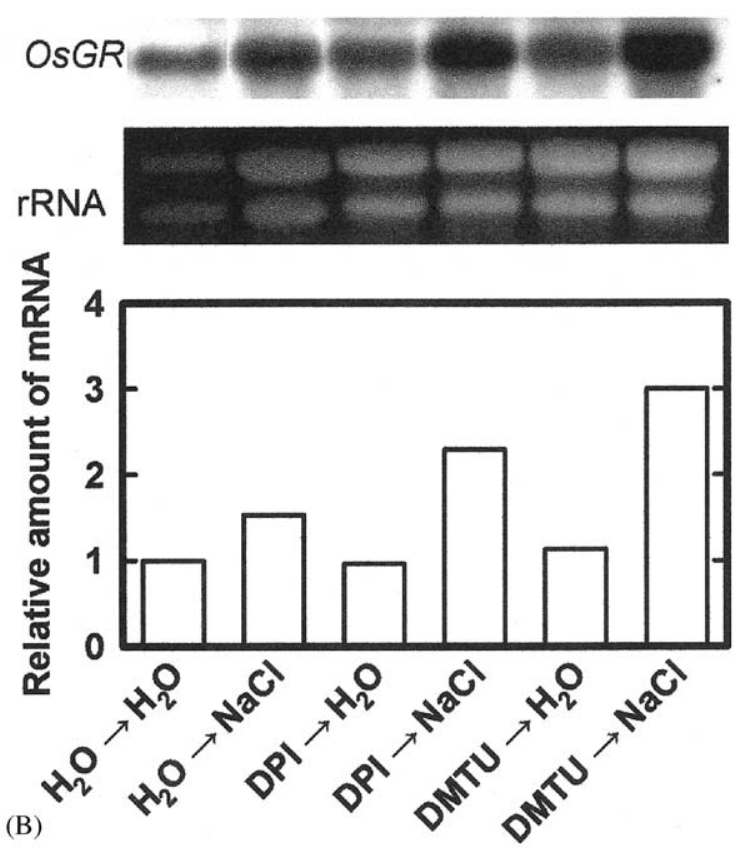

Figure 3. Effect of DPI and DMTU pre-treatments on mRNA abundance of OSAPX (A) and OsGR (B) in roots of rice seedlings in the presence or absence of $\mathrm{NaCl}$. Two-day-old rice seedlings were pre-treated with distilled water, DPI $\left(0.1 \mu \mathrm{mol} \mathrm{L} \mathrm{L}^{-1}\right)$, or DMTU $\left(5 \mathrm{mmol} \mathrm{L} \mathrm{L}^{-1}\right)$ for $12 \mathrm{~h}$ and then transferred to distilled water and $\mathrm{NaCl}\left(150 \mathrm{mmol} \mathrm{L}^{-1}\right)$ for $24 \mathrm{~h}$, respectively. Northern blots of total RNA samples were hybridized with OsAPX (A) and OsGR (B). The values of mRNA of OsAPX and OSGR were adjusted by its corresponding amount of rRNA for equality of loading. After the adjustment of rRNA, the reaction with roots in water was treated as the normalized reference, with a value of one, for determining the relative amount of mRNA of OsAPX and OsGR.
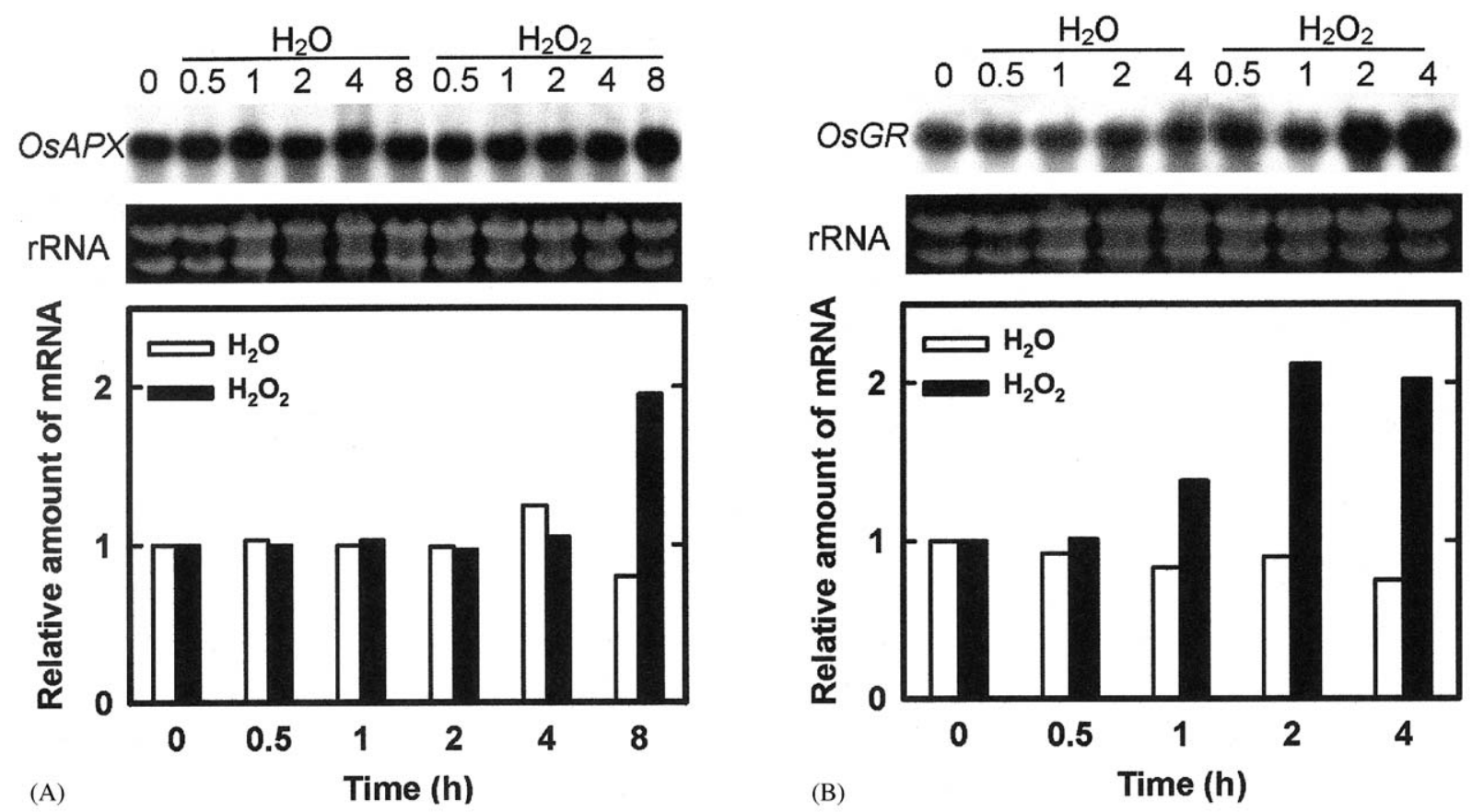

Figure 4. Changes in mRNA abundance of $\operatorname{OsAPX}(\mathrm{A})$ and $\operatorname{OsGR}(\mathrm{B})$ in roots of rice seedlings in the presence or absence of $\mathrm{H}_{2} \mathrm{O}_{2}$. Two-day-old rice seedlings were treated either with distilled water or $\mathrm{H}_{2} \mathrm{O}_{2}\left(10 \mathrm{mmol} \mathrm{L}{ }^{-1}\right)$. Northern blots of total RNA samples were hybridized with $\operatorname{OsAPX}(\mathrm{A})$ and $O s G R(\mathrm{~B})$. The values of mRNA of OsAPX and OsGR were adjusted by its corresponding amount of rRNA for equality of loading. After the adjustment of rRNA, the reaction with roots in water was treated as the normalized reference, with a value of one, for determining the relative amount of mRNA of OsAPX and OsGR. 
et al. (1996) reported that APX activity, not the mRNA level, was enhanced by $\mathrm{NaCl}$-stressed $R$. sativus plants. In the present study, we observed that $\mathrm{NaCl}$ treatment resulted in an enhancement of $O s A P X$ and $O s G R$ in the roots of rice seedlings (Figs. $3 \mathrm{~A}$ and $\mathrm{B}$ ). Our results reveal that $O S A P X$ and $O S G R$ gene expression is upregulated by $\mathrm{NaCl}$ in rice roots.

Induction of $A P X$ and $G R$ expression by $\mathrm{H}_{2} \mathrm{O}_{2}$ has been reported (Karpinski et al., 1999; Morita et al., 1999). In agreement with these findings, both OsAPX and OsGR expression in rice roots were enhanced by $\mathrm{H}_{2} \mathrm{O}_{2}$ (Figs. 4A and $\mathrm{B}$ ). It has been suggested that cytosolic $A P X$ transcripts can be upregulated by increased levels of $\mathrm{H}_{2} \mathrm{O}_{2}$ in tobacco chloroplasts as results of $\mathrm{Cu}-\mathrm{Zn}$-superoxide dismutase overexpression (Gupta et al., 1993). de Agazio and Zacchini (2001) showed that induced-of APX expression in spermidine-treated maize roots was mediated though $\mathrm{H}_{2} \mathrm{O}_{2}$. However, to our knowledge, the involvement of $\mathrm{H}_{2} \mathrm{O}_{2}$ in regulating $\mathrm{GR}$ expression has not been examined. In the present study, we observed that DPI and IMD, which reduced $\mathrm{NaCl}$-induced accumulation of $\mathrm{H}_{2} \mathrm{O}_{2}$ (Fig. 2A), did not inhibit $\mathrm{NaCl}$-enhanced activities of $\mathrm{APX}$ and GR (Figs. 2B and C) and expression of OsAPX and OsGR (Figs. $3 \mathrm{~A}$ and $\mathrm{B}$ ). Similarly, $\mathrm{NaCl}$-enhanced activities of APX and GR and expression of OSAPX and OsGR were not reduced by DMTU, a chemical trap for $\mathrm{H}_{2} \mathrm{O}_{2}$ (Figs. 2B, C, 3A, and B). Our results suggest that $\mathrm{NaCl}$-enhanced activities of $\mathrm{APX}$ and GR and expression of OsAPX and OsGR are not mediated through $\mathrm{H}_{2} \mathrm{O}_{2}$ in rice roots. We have measured total root $\mathrm{H}_{2} \mathrm{O}_{2}$ levels; however, different subcellular activities of antioxidant enzymes could interact the cell to create local differences of $\mathrm{H}_{2} \mathrm{O}_{2}$ levels in different cellular compartments and therefore, we cannot exclude the involvement of $\mathrm{H}_{2} \mathrm{O}_{2}$ in this signaling pathway in rice roots during $\mathrm{NaCl}$ stress.

\section{Acknowledgements}

This work was supported financially by grant NSC 92-2313-B-002-001 from the National Science Council of the Republic of China.

\section{References}

Aono M, Kubo A, Saji, Natori T, Tanaka K, Kondo N. Resistance to active oxygen toxicity of transgenic Nicotiana tabacum that expresses the gene for glutathione reductase from Escherichia coli. Plant Cell Physiol 1991;32:691-7.
Babiychuk E, Kushnir S, Belles-Boix E, Van Montagu M, Inzé D. Arabidopsis thaliana oxidoreductase homologs confer tolerance of yeasts toward the thioloxidizing drug diamide. J Biol Chem 1995;270: 26224-31.

Blokhina OB, Chirkova TV, Fagerstedt KV. Anoxic stress leads to hydrogen peroxide formation in plant cells. J Exp Bot 2001;52:1179-90.

Bolwell GP, Davies DR, Gerrish C, Auh C- K, Murphy TM. Comparative biochemistry of the oxidative burst produced by rose and French bean cells reveals two distinct mechanisms. Plant Physiol 1998;116: 1379-85.

Bowler C, Van Montagu M, Inze D. Superoxide dismutase and stress tolerance. Annu Rev Plant Physiol Plant Mol Biol 1992;43:83-116.

Broadbent P, Greissen GP, Kular B, Wellburn, Mullineaux PM. Oxidative stress responses in transgenic tobacco containing altercated levels of glutathione reductase activity. Plant J 1995;8:247-55.

Cross AR. Inhibitors of the leukocyte superoxide generating oxidase: mechanisms of action and methods for their elucidation. Free Radical Biol Med 1990;8: 71-93.

Dat JF, Lopez-Delgado H, Foyer CH, Scott IM. Parallel changes in $\mathrm{H}_{2} \mathrm{O}_{2}$ and catalase during thermotholarance induced by salicylic acid or heat acclimation in mustard seedlings. Plant Physiol 1998;116:1351-7.

de Agazio M, Zacchini M. Dimethylurea, a hydrogen peroxide trap, partially prevents stress effects and ascorbate peroxidase increase in spermidine-treated maize roots. Plant Cell Environ 2001;24:237-44.

del Rio LA, Corpas FJ, Sandalio LM, Palme JM, Gómez M, Barroso JB. Reactive oxygen species, antioxidant systems and nitric oxide in peroxisomes. J Exp Bot 2002;53:1255-72.

Dionisio-Sese ML, Tobita S. Antioxidant responses of rice seedlings to salinity stress. Plant Sci 1998;135:1-9.

Fadzilla NM, Gill V, Finch RP, Burdon RH. Chilling, oxidative stress and antioxidant responses in shoot cultures of rice. Planta 1996;199:552-6.

Fadzilla NM, Finch RP, Burdon RH. Salinity, oxidative stress and antioxidant responses in shoot cultures of rice. J Exp Bot 1997;48:325-31.

Foster JG, Hess JL. Superoxide dismutase and glutathione reductase activities in cotton leaf tissue exposed to an atmosphere enriched in oxygen. Plant Physiol 1980;66:482-7.

Foyer CH, Lopez-Delzado H, Dat JF, Scott IM. Hydrogen peroxide- and glutathione-associated mechanisms of acclimatory stress tolerance and signalling. Physiol Plant 1997;100:241-54.

Frahry G, Schopfer P. Inhibition of $\mathrm{O}_{2}^{-}$reducing activity of horseradish peroxidase by diphenyleneiodonium. Phytochemistry 1998;48:223-7.

Gupta AS, Webb RP, Holaday AS, Allen RD. Overexpression of superoxide dismutase protects plants from oxidative stress. Induction of ascorbate peroxidase in superoxide dismutase-overexpression plants. Plant Physiol 1993;103:1067-73. 
Hernández JA, Almansa MS. Short term effects of salt stress on antioxidant systems and leaf water relations of pea leaves. Physiol Plant 2002;115:251-7.

Hernández JA, Ferrer MA, Jaménez A, Ros-Barceló A, Sevilla $\mathrm{F}$. Antioxidant system and $\mathrm{O}_{2}^{-} / \mathrm{H}_{2} \mathrm{O}_{2}$ production in the apoplast of Pisum sativum L. leaves: its relation with $\mathrm{NaCl}$-induced necrotic lesons in minor veins. Plant Physiol 2001;127:817-31.

Jana S, Choudhuri MA. Glycolate metabolism of three submerged aquatic angiosperms during aging. Aquat Bot 1981;12:345-54.

Jiang $M$, Zhang J. Water-stress-induced abscisic acid accumulation triggers the increased generation of reactive oxygen species and up-regulated the activities of antioxidant enzymes in maize leaves. J Exp Bot 2002;53:2401-10.

Jiang $M$, Zhang J. Cross-talk between calcium and reactive oxygen species originated from $\mathrm{NADPH}$ oxidase in abscisic acid-induced antioxidant defence in leaves of maize seedlings. Plant Cell Environ 2003;26:929-39.

Kaminaka H, Morita S, Nakajima M, Masumura T, Tanaka $\mathrm{H}$. Gene cloning and expression of cytosolic glutathione reductase in rice (Oryza sativa L.). Plant Cell Physiol 1998;39:1269-80.

Karpinski S, Excobar C, Karpinska B, Creissen G, Mullineaux PM. Photosynthetic electron transport regulates the expression of cytosolic ascorbate peroxidase genes in Arabidopsis during excess light stress. Plant Cell 1997;9:627-40.

Karpinski S, Reynolds H, Karpinska B, Wingsle G, Creissen $G$, Mullineaux P. Systemic signaling and acclimation in response to excitation energy in Arabidopsis. Science 1999;284:654-7.

Kawasaki S, Borchert C, Deyholos M, Wang H, Brazille S, Kawai K, Galbraith D, Bohnert HJ. Gene expression profiles during the initial phase of salt stress in rice. Plant Cell 2001;13:889-905.

Kubo A, Saji H, Tanaka K, Kondo N. Expression of Arabidopsis cytosolic ascorbate peroxidase gene in response to ozone or sulfur dioxide. Plant Mol Biol 1995;29:479-89.

Lee $\mathrm{DH}$, Kim YS, Lee CB. The inductive responses of the antioxidant enzymes by salt stress in the rice (Oryza sativa L.). J Plant Physiol 2001;158:737-48.

Lin $\mathrm{CC}$, Kao $\mathrm{CH}$. Effect of $\mathrm{NaCl}$ stress on $\mathrm{H}_{2} \mathrm{O}_{2}$ metabolism in rice leaves. Plant Growth Regul 2000;30: 151-5.

Lin $\mathrm{CC}$, Kao $\mathrm{CH}$. Cell wall peroxidase activity, hydrogen peroxide level and $\mathrm{NaCl}$-inhibited root growth of rice seedlings. Plant Soil 2001;230:135-43.

Lopez F, Vansuyt G, Casse-Delbart F, Fourcroy P. Ascrobate peroxidase activity, not the mRNA level, is enhanced in salt-stressed Raphanus sativus plants. Physiol Plant 1996;97:13-20.

Morita S, Kaminaka H, Masumura T, Tanaka K. Induction of rice cytosolic ascorbate peroxidase mRNA by oxidative stress; the involvement of hydrogen peroxide in oxidative signaling. Plant Cell Physiol 1999; 40:417-22.
Munns R. Physiological responses limiting plant growth in saline soils: some dogma and hypothesis. Plant Cell Environ 1993;16:15-24.

Murphy TM, Huerta AJ. Hydrogen peroxide formation in cultured rose cells in response to UV-C radiation. Physiol Plant 1990;78:247-53.

Nakano Y, Asada K. Hydrogen peroxide is scavenged by ascorbate-specific peroxidase in spinach chloroplast. Plant Cell Physiol 1981;22:867-80.

Neill S, Desikan R, Hancock J. Hydrogen peroxide signaling. Curr Opin Plant Biol 2002;5:386-95.

O'Kane D, Gill V, Boyd P, Burdon R. Chilling, oxidative stress and antioxidant response in Arabidopsis thaliana callus. Planta 1996;198:371-7.

Okuda T, Matsuda Y, Yamanaka A, Sagisaka S. Abrupt increase in the level of hydrogen peroxide in leaves of winter wheat is caused by cold treatment. Plant Physiol 1991;97:1265-7.

Orozco-Cárdenas ML, Narváez-Vásquez J, Ryan CA. Hydrogen peroxide acts as a second messenger for the induction of defense genes in tomato plants in response to wounding, systemin, and methyl jasmonate. Plant Cell 2001;13:179-91.

Pastori GM, Trippi VS. Oxidative stress induces high rate of glutathione reductase synthesis in a droughtresistant maize strain. Plant Cell Physiol 1992;33: 957-61.

Pastori GM, Trippi VS. Antioxidant protection in a drought-resistant maize strain during leaf senescence. Physiol Plant 1993;87:227-31.

Pei Z-W, Murata Y, Banning G, Thomine S, Klusener B, Allen GJ, Grill E, Schroeder JI. Calcium channels activated by hydrogen peroxide mediate abscisic acid signalling in guard cells. Nature 2000;406:731-4.

Prasad TK, Anderson MD, Martin BA, Stewart CR. Evidence for chilling-induced oxidative stress in maize seedlings and a regulatory role for hydrogen peroxide. Plant Cell 1994;6:65-74.

Sambrook J, Fritsch EF, Maniatis T. Molecular cloning: a laboratory manual. Cold Spring Harbor, New York, NY: Cold Spring Harbor Laboratory Press; 1989.

Sato Y, Murakami T, Funatsuki H, Matsuba S, Saruyama H, Tarida M. Heat-shock-mediated APX gene expression and protection against chilling injury in rice seedlings. J Exp Bot 2001;52:145-51.

Savoure A, Thorin D, Davey M, Hua X-J, Mauro S, Van Montagu $\mathrm{M}$, Inzé D, Verbruggen $\mathrm{N}$. $\mathrm{NaCl}$ and $\mathrm{CuSO}_{4}$ treatments trigger distinct oxidative defense mechanisms in Nicotiana plumbaginifolia L. Plant Cell Environ 1999;22:387-96.

Smirnoff $N$. The role of active oxygen in the response of plants to water deficit and desiccation. New Phytol 1993;125:27-58.

Stuehr DJ, Fasehun OA, Kwon NS, Gross SS, Gonzalez JA, Levi R, Nathan CF. Inhibition of macrophage and endothelial cell nitric oxide synthase by diphenyleneiodonium and its analog. FASEB J 1991;5: 98-103.

Sudhakar C, Lakshmi A, Gridarakuman S. Changes in the antioxident enzymes efficacy in two high yielding 
genotypes of mulberry (Morus alba L.) under $\mathrm{NaCl}$ salinity. Plant Sci 2001;161:613-9.

Thomas PS. Hybridization of denatured RNA transferred on dotted nitro cellulose paper. Methods Enzymol 1983;100:255-66.

Van Breusegem FV, Vranova E, Dat JF, Inzé D. The role of active oxygen species in plant signal transduction. Plant Sci 2001;161:405-14.
Vansuyt G, Lopez F, Inzé D, Briat J-F, Fourcroy P. Iron triggers a rapid induction of ascorbate peroxidase gene expression in Brassica napus. FEBS Lett 1997;410:195-200.

Xiang C, Oliver DJ. Glutathione metabolic genes coordinately respond to heavy metals and jasmonic acid in Arabidopsis. Plant Cell 1998;10: 1539-50. 